\title{
Factors Affecting Successful Implementation of Electronic Procurement in Government Institutions Based on the Technology Acceptance Model
}

\author{
Clara Kabwela Kademaunga ${ }^{1}$, Jackson Phiri ${ }^{2}$ \\ ${ }^{1}$ Graduate School of Business, University of Zambia, Lusaka, Zambia \\ ${ }^{2}$ Department of Computer Science, School of Natural Sciences, University of Zambia, Lusaka, Zambia \\ Email: kclarakabwela@yahoo.com, jackson.phiri@cs.unza.zm
}

How to cite this paper: Kademaunga, C.K. and Phiri, J. (2019) Factors Affecting Successful Implementation of Electronic Procurement in Government Institutions Based on the Technology Acceptance Model. Open Journal of Business and Management, 7, 1705-1714.

https://doi.org/10.4236/ojbm.2019.74118

Received: June 6, 2019

Accepted: September 21, 2019

Published: September 24, 2019

Copyright $\odot 2019$ by author(s) and Scientific Research Publishing Inc. This work is licensed under the Creative Commons Attribution International License (CC BY 4.0).

http://creativecommons.org/licenses/by/4.0/

\begin{abstract}
Electronic procurement has continued to gain ground in many organisations world over both in government and private institutions as a basis for competitive procurement and good practice. African countries have also started implementing electronic procurement and Zambia is no exception. Electronic procurement when well implemented has many organisational advantages to be gained by respective institutions that implement these reforms. In this paper, the aim was to identify the factors affecting successful implementation of electronic procurement in government institutions based on the Technology Acceptance Model (TAM). A baseline study was conducted for a targeted population of 100 respondents purposively selected, drawn from Information Technology, Procurement and Finance Departments. Data were collected through the questionnaires. Statistical correlation was used in data analysis in order to assess the level of adoption and usage of electronic procurement based on the TAM model. The study findings revealed that perceived ease of use and intention to use was positive. This implies that the personnel in most government institutions were ready to embrace electronic procurement implementation reforms largely due to ease of use and usefulness of the electronic system. However, the study revealed that not much was being done by top management in respective institutions regarding the implementation of electronic procurement.
\end{abstract}

\section{Keywords}

Electronic Procurement, Implementation, Information Technology, Technology Acceptance Model, Zambia Public Procurement Authority 


\section{Introduction}

Technology in recent time has been viewed as one of the cornerstones that drives many organizations in the competitive business world by reducing costs (paperless transactions), reducing transactional time and improving transparency through the automation of transactions [1]. The Zambian government through the Zambia Public Procurement Authority (ZPPA) is moving towards electronic procurement (e-procurement) [2]. ZPPA in 2016 introduced electronic government procurement (e-GP) for all companies and government institutions [2]. Despite this government pronouncement, not much is being done by ZPPA and many other institutions on implementation of e-procurement. Electronic Government Procurement (e-GP) is the use of information and Communications Technology by government agencies and other actors of the procurement community in conducting all activities of Government Procurement Process Cycle for the acquisition of goods, works, and services with good governance in procurement management [3] [4]. Zambia Public Procurement Authority (ZPPA) acknowledges that the country's e-procurement system would reduce malpractice and improve efficiency in monitoring bids and contracts. Interested bidders, would be able to submit their offers from anywhere in the world [5]. Bidders would have automated compliance validation during bid submissions [4] [5]. The system will curb corruption because it will reduce face-to-face transactions and there will be anonymity of bidders until bids are opened [6].

The rest of this paper is arranged as follows: The literature review is given in Section 2, the research methodology in Section 3, while the results are given in Section 4. Finally, the Discussion and Conclusion are given in Section 5 and Section 6 respectively.

\section{Literature Review}

Procurement (Supply) usually represents one of the largest expense items in a firm's cost structure [3]. It is significant to acknowledge that, because the procurement function did not establish itself within the academic ranks and research institutions until recent years, a search of contemporary literature on the subject shows little evidence that public procurement has penetrated the theoretical boundaries of academic research, despite the profession's efforts over a decade to enhance, develop, and improve its profile in the eye of other professions [6] [7].

\subsection{Factors Affecting Electronic Procurement in Organisations}

Some of the challenges inhibiting the successful implementation of electronic procurement in an African context include difficulties in selling the e-procurement concept internally to organizational stakeholders such as senior management and end-users, a lack of confidence, a fear of making errors, lack of technology and innovation champions within the organizations which had inhibited full acceptance of the process as indicated by [8] in their study in Kenya. The other 
factors highlighted in this study include the size of the firm and organization readiness [8]. A study on e-procurement adaptation in Greece [9], pointed out e-procurement strategy, re-engineering of procurement processes and management of expectations as key success factors in an E-procurement adaptation strategy. Their study shows that implementation must be achieved in a manner of "incremental change" where technological solutions apply to regulations and policies.

\subsection{Technology Acceptance Model (TAM)}

Technology Acceptance Model (TAM) is a model used in modelling users' acceptance of information systems or technologies [10]. Figure 1 shows the technology transfer model proposed by Davis in 1986. The model that was adopted for the purpose of this research was [11] and [12]. The author in [11] used the TAM model to show the level of use and adoption of E-Tax by the Zambian Revenue Authority. The author in [12] on the other hand used the TAM model to show the level of adoption of Mobile Application by Banks in Zambia. In study will adopt the TAM model to assess the level of adoption of E-procurement in Zambia. According to TAM, there are two specific variables that are fundamental determinants of users' attitude toward using information technology and actual use of the system: perceived usefulness and perceived ease of use relatively to new information system design features [8].

\section{Perceived Ease-of-Use (PEOU)}

The degree to which a person believes that using particular system would be free from effort. Perceived ease of use can contribute in an instrumental way in improving a person's performance. Due to the fact that the user will have to deploy less effort with a tool that is easy to use, he will be able to spare efforts to accomplish other tasks [10] [11] [12].

Perceived Usefulness (PU) and Intention to Use

The degree to which a person believes that using a particular system would

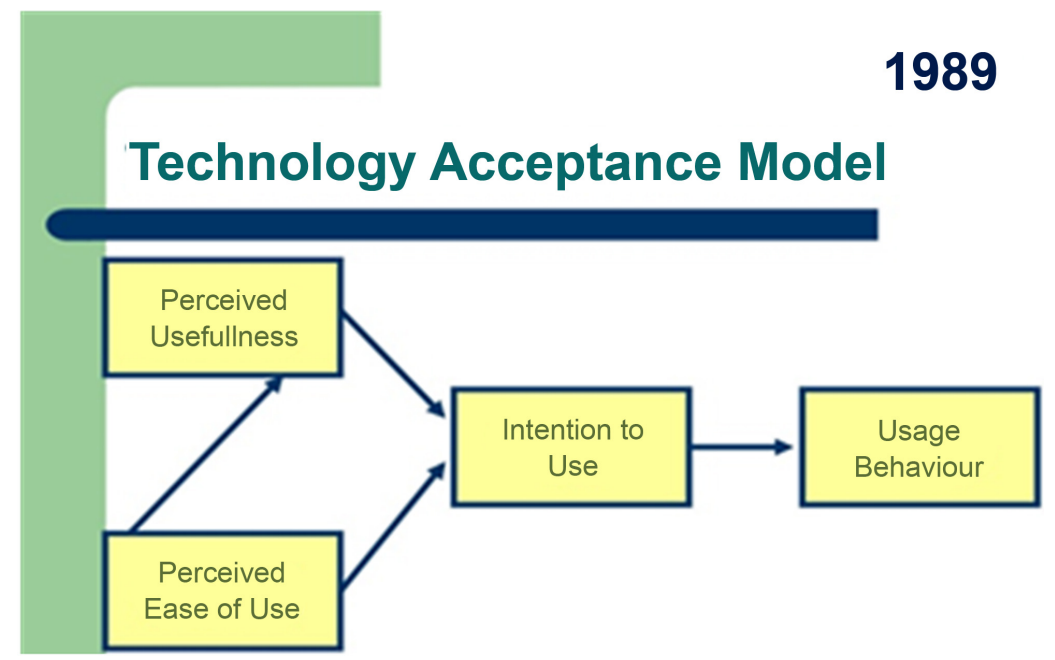

Figure 1. Original technology transfer model (Davis, 1986). 
enhance his or her job performance. Perceived ease of use also influences in a significant way the attitude of an individual through two main mechanisms: self-efficacy and instrumentality [10] [11] [12] [13].

\subsection{Electronic Procurement Implementation in Africa}

Many countries on the African continent have developed and rolled out or are in the process of rolling out e-procurement across their countries for the whole procurement sector [3] [14]. Rwanda was the first African country to implement e-procurement; many other countries took several years to pilot e-procurement systems and were slow to use E-procurement at the sub-national and local levels. As of 2018, Zambia had joined Rwanda as one of the pioneers of e-procurement in Africa, and other countries were beginning to follow suit. Rwanda and Zambia have broken the myth that e-procurement could not be done in Africa, which has created a ripple effect across the continent, which has seen Tanzania, Ugan$\mathrm{da}$, and other African countries sign contracts to implement e-procurement [14].

\section{Research Methodology}

Quantitative survey design was used in this study [15]. The study population comprised of personnel from Information Technology, Finance and Supply (Procurement) Departments based in Lusaka Province in Zambia. The population was purposively sampled targeting the intended users of electronic procurement platform and was determined by the use of the formula below [16];

$$
n=N /\left[1+N(e)^{2}\right]
$$

Equation (1) was used in determining the sample size used in the study. In Equation (1):

- $n$ was the sample size,

- $N$ represented the population and

- $e$ was the level of precision.

With 5\% confidence level, a sample size of 100 was arrived at with a total of 100 questionnaires distributed which had a 100\% response rate from the targeted respondents.

\section{Data Collection, Analysis and Interpretation}

Primary data was obtained through questionnaire administration. A review of relevant literature was conducted from similar studies as a source of secondary data to gain an in depth understanding of the subject. The data was analyzed using the statistical package for social science [17]. The statistical analysis was based on Pearson coefficient correlation and P-Values. Figure 2 below highlights the modified Technology Acceptance Model (TAM) used in this study adapted from the original TAM in Figure 1. The modified model has five variables; perceived usefulness, perceived ease of use, intention to use, management adoption, support infrastructure and change management. The study looked 


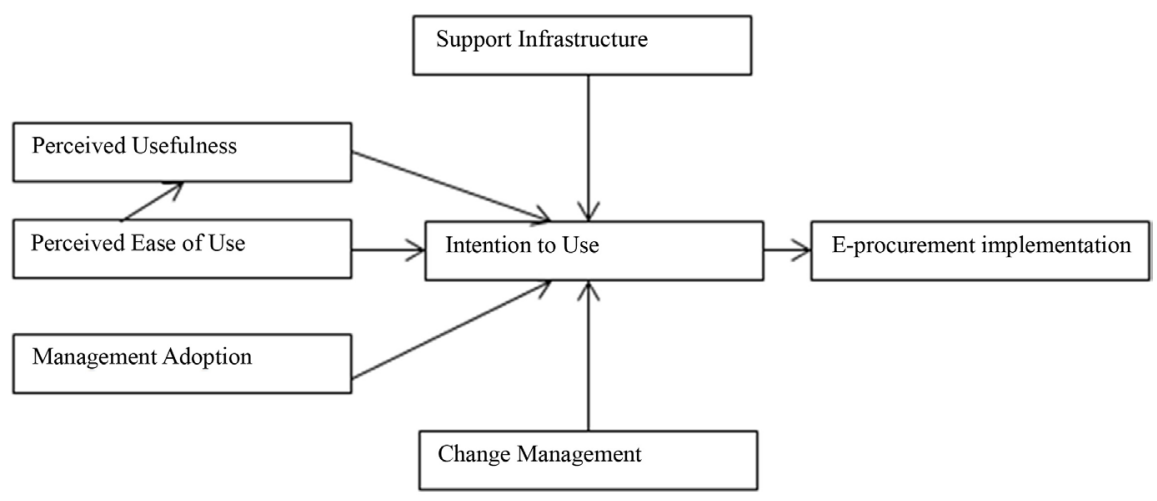

Figure 2. Modified TAM for e-procurement system implementation.

at these factors in relation to their impact on electronic procurement implementation in government institutions. This was in an effort to assess the prevailing conditions in governments institutional.

\section{Results}

The section looks at the result findings based on the model of study indicated in Figure 2 above. Correlation and P-Values were used in this study.

\subsection{General Statistics}

In this study, Information Technology, Finance and Supply Departments had the following representations; 26\% Information Technology (IT), 29\% Finance and $45 \%$ Supply Department respectively as highlighted in Table 1.

Figure 3 shows $69 \%$ male representation, 30\% female representation while 1\% depicts the non-disclosure of gender representation across the three departments.

Education has an impact on the adaptability of easy transition of personnel to using new technologies and innovations. The results in Figure 4 show that the majority of the respondents had a diploma qualification at 39\%, 13\% at degree level, while $42 \%$ had elementary qualification below a diploma with $5 \%$ of respondents having postgraduate qualification.

On average the ICT general knowledge ranges from very good to moderate at 95\% with those rate poor at $5 \%$ as shown in Figure 5.

\subsection{Correlation Coefficient and P-Values}

Correlation and P-Values test were analysed through the use of the Technology Acceptance Model. Correlation analysis is used to establish if there exists relationship between two or more variables which lies between strong negative correlation and perfect positive correlation. Correlation coefficient was tested on perceived ease of use, intention to use and usefulness. Table 2 looked at personnel readiness to embrace electronic procurement systems, electronic procurement job enhancement and task completion and regularly usage of platform to interact with other users. 
Table 1. Functions researched.

\begin{tabular}{ccccc}
\hline Functions Researched & Frequency & Percent & Valid Percent & Cumulative Percent \\
\hline Information Technology & 26 & 26.0 & 26.0 & 26.0 \\
Finance & 29 & 29.0 & 29.0 & 55.0 \\
Supply & 45 & 45.0 & 45.0 & 100.0 \\
\hline
\end{tabular}

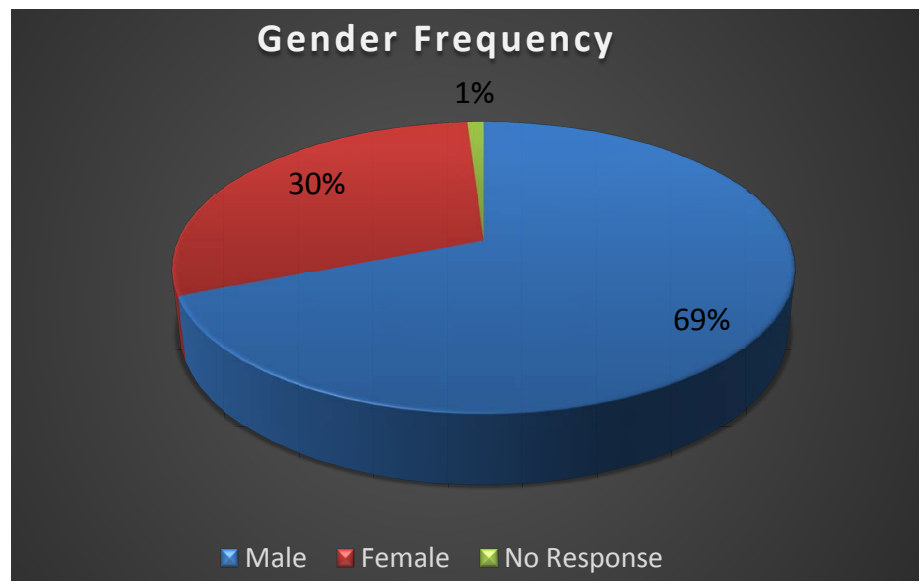

Figure 3. Gender distribution of respondents.

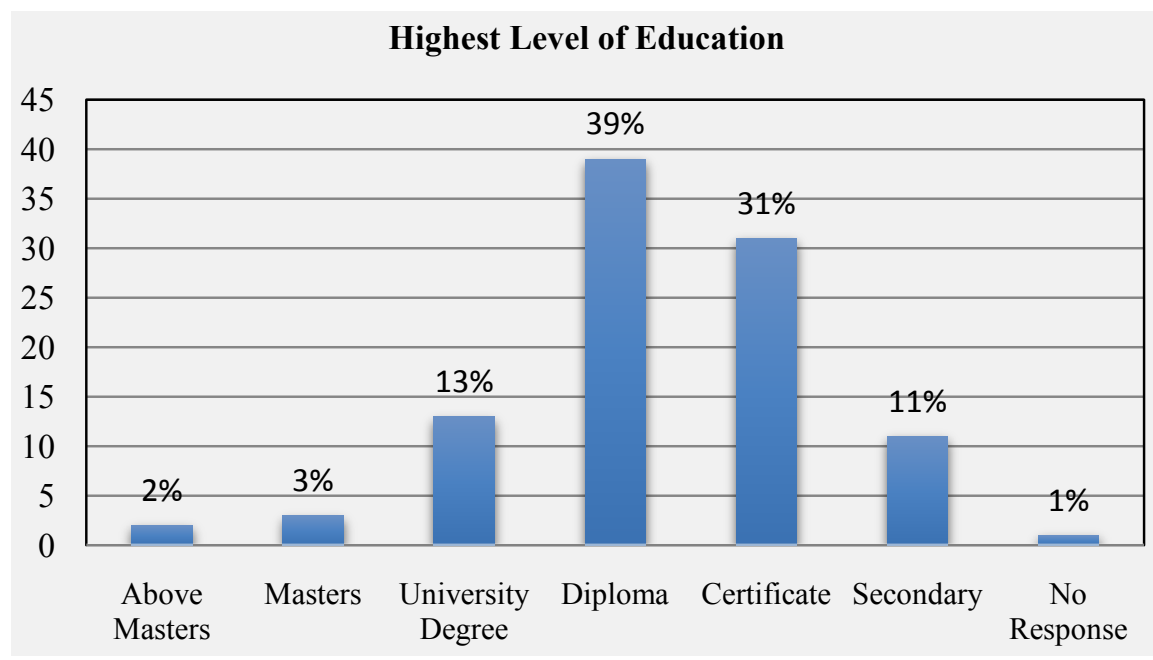

Figure 4. Highest level of education.

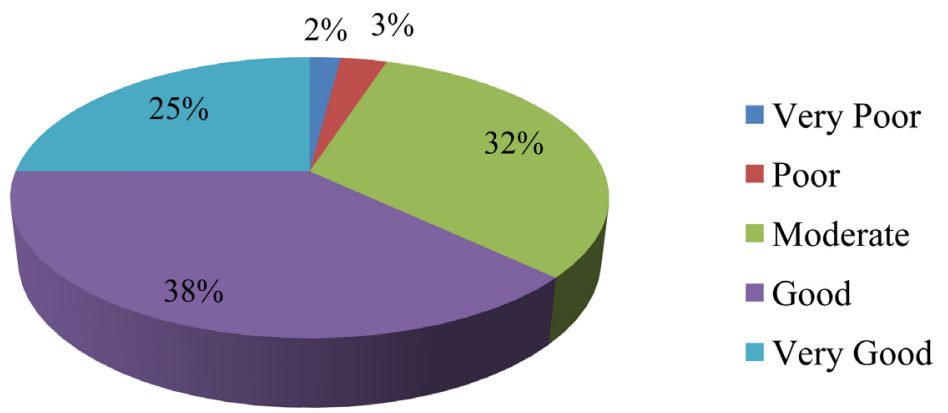

Figure 5. General computer knowledge. 
Table 2. Output of results.

\begin{tabular}{|c|c|c|c|c|}
\hline & & $\begin{array}{l}\text { Personnel } \\
\text { Readiness }\end{array}$ & $\begin{array}{l}\text { Performance } \\
\text { Enhancement }\end{array}$ & Platform Usage \\
\hline \multirow{3}{*}{ Personnel Readiness } & Pearson Correlation & 1 & -0.020 & -0.047 \\
\hline & Sig. (2-tailed) & & 0.842 & 0.650 \\
\hline & $\mathrm{N}$ & 100 & 100 & 97 \\
\hline \multirow{3}{*}{$\begin{array}{l}\text { Performance } \\
\text { Enhancement }\end{array}$} & Pearson Correlation & -0.020 & 1 & $0.212^{*}$ \\
\hline & Sig. (2-tailed) & 0.842 & & 0.037 \\
\hline & $\mathrm{N}$ & 100 & 100 & 97 \\
\hline \multirow{3}{*}{$\begin{array}{l}\text { Regularly usage of the } \\
\text { platform to interact } \\
\text { with other users }\end{array}$} & Pearson Correlation & -0.047 & $0.212^{*}$ & 1 \\
\hline & Sig. (2-tailed) & 0.650 & 0.037 & \\
\hline & $\mathrm{N}$ & 97 & 97 & 97 \\
\hline
\end{tabular}

${ }^{*}$ Correlation is significant at the 0.05 level (2-tailed).

The variables above on personnel readiness and platform usage to interact with other users (intention to use) have a significant value of greater than 0.05 which deduces a negative relationship the $(\mathrm{P}=0.650040<0.05)$. Therefore, there is no relationship between perceived usefulness and intention as they do not affect implementation of E-procurement. Furthermore, the correlation between enhancement of job performance enhancement and platform usage found a significant value is less than 0.05 deduced a strong relationship. This showed that perceived usefulness and intention to use have a strong association with the implementation of E-procurement.

Table 3 looked at internet usage experience, electronic procurement promoting interdepartmental collaboration and need for further training in information technology.

The variables above indicate that electronic procurement usage promotes interdepartmental collaboration, fosters team work and general knowledge of computers have significant values less than 0.05 as the $(\mathrm{P}=0.037906<0.05)$ which meant that there is a strong relationship. Perceived usefulness and perceived ease to use has a significant effect on implementation of E-procurement. The correlation on general knowledge of computers and need for further training in information and technology have a significant value less than 0.05 as the $(\mathrm{P}=0.003020<0.05)$ which suggest that a strong relationship exists as well. This shows that perceived ease of use and intention to use has a significant effect on implementation of E-procurement. The results showed that perceived ease of use and intention to use has a significant effect on implementation of E-procurement. Perceived usefulness and intention to use also has significant effect on implementation of E-procurement. We therefore conclude that from the results above, the both the perceived usefulness and perceived ease to use have a significant effect on implementation of E-procurement in government institutions.

\section{Discussion}

The statistical results based on Figure 3, show positive response in terms of the 
Table 3. Output of results.

\begin{tabular}{|c|c|c|c|c|}
\hline & & $\begin{array}{l}\text { Internet usage } \\
\text { experience }\end{array}$ & $\begin{array}{l}\text { interdepartmental } \\
\text { collaboration }\end{array}$ & $\begin{array}{l}\text { Training in } \\
\text { information technology }\end{array}$ \\
\hline \multirow{3}{*}{$\begin{array}{l}\text { Internet usage } \\
\text { experience }\end{array}$} & Pearson Correlation & 1 & 0.023 & $0.272^{\star \star}$ \\
\hline & Sig. (2-tailed) & & 0.821 & 0.007 \\
\hline & $\mathrm{N}$ & 99 & 99 & 98 \\
\hline \multirow{3}{*}{$\begin{array}{l}\text { Interdepartmental } \\
\text { collaboration }\end{array}$} & Pearson Correlation & 0.023 & 1 & $0.251^{*}$ \\
\hline & Sig. (2-tailed) & 0.821 & & 0.012 \\
\hline & $\mathrm{N}$ & 99 & 100 & 99 \\
\hline \multirow{3}{*}{$\begin{array}{l}\text { Training in } \\
\text { information } \\
\text { technology }\end{array}$} & Pearson Correlation & $0.272^{* *}$ & $0.251^{*}$ & 1 \\
\hline & Sig. (2-tailed) & 0.007 & 0.012 & \\
\hline & $\mathrm{N}$ & 98 & 99 & 99 \\
\hline
\end{tabular}

${ }^{*}$ Correlation is significant at the 0.05 level (2-tailed).

usefulness and easy to use of the e-procurement system once fully implemented. The proposed modified TAM Model if embraced by the government would very useful in actualisation of e-procurements and the benefit that comes with automation. One of the major challenges that were highlighted in the study was the need for infrastructure. This is a common problem in most developing countries. E-procurement cannot be realised if the necessary infrastructure is not available. People have to be educated on the positive effects the system comes with. Therefore, the modified TAM Model in Figure 3, if used correctly, can enable a smooth implementation of the E-procurement system. From the results obtained above in Table 3, the following are the general recommendations that will need to be taken into account for successful implementation of e-procurement in developing countries.

1) Create awareness on electronic procurement through continuous learning interactive programs such as workshops and refresher courses.

2) Ensure all the necessary electronic procurement pre-requisite are in place for successful implementation of the reform and also promoting top leadership interdepartmental collaboration to foster E-procurement implementation.

3) Respective institution should collaborate with other government institutions and private sector organizations both within and outside the country with interest in the implementation of electronic procurement.

\section{Conclusion}

The study was looking at the factors affecting successful implementation of electronic procurement in government institutions based on the technology Acceptance Model. In order to achieve the aim of the study, primary data were corrected from respondents through questionnaires and secondary data through a review of literature relevant to the study. The results obtained from the study show that once fully implemented, e-procurement will be easy to use and will be 
very useful in addressing most of the challenges faced by government institutions using paper based on none automated systems. The positive effects include promoting interdepartmental collaboration; enhancing job and task completion, fostering team work among others. The correlation tests results in Table 2 and Table 3 above based on TAM model (perceived ease of use and perceived usefulness) showed positive correlation with implementation and using e-procurement in government institutions.

\section{Acknowledgements}

We wish to acknowledge all those who participated and took time to respond to the questionnaires.

\section{Conflicts of Interest}

The authors declare no conflicts of interest regarding the publication of this paper.

\section{References}

[1] Muyumba, T. and Phiri, J. (2017) A Web Based Inventory Control System Using Cloud Architecture and Barcode Technology for Zambia Air Force. International Journal of Advanced Computer Science and Applications, 8, 132-142.

https://doi.org/10.14569/IJACSA.2017.081117

[2] Zambia Public Procurement Authority (2008) Electronic Government Procurement System (E-GP). https://www.zppa.org.zm

[3] Milambo, D. and Phiri, J. (2019) Aircraft Spares Supply Chain Management for the Aviation Industry in Zambia Based on the Supply Chain Operations Reference (SCOR) Model. Open Journal of Business and Management, 7, 1183-1195. https://doi.org/10.4236/ojbm.2019.73083

[4] Kumar Shakya, R. (2015) Good Governance in Public Procurement: An Evaluation of the Role of an E-Procurement System. Capella University, Minneapolis, MN.

[5] Nyondo, L. (2016) Lusaka, ZPPA Introduces Electronic Procurement System; Zambia Daily Mail, Lusaka, Zambia.

[6] Ilhan, N. and Rahim, M. (2017) Benefits of E-Procurement Systems Implementation: Experience of an Australian Municipal Council. In: Advances in Electronic Government, Digital Divide, and Regional Development, IGI Global, Hershey, PA, 277-294.

[7] Matthew, D. (2005) Strategic Procurement in the Public Sector: A Mask for Financial and Administrative Policy. Journal of Public Procurement, 5, 388-399. https://doi.org/10.1108/JOPP-05-03-2005-B005

[8] Oporo, M. (2014) Dynamic Procurement Practices and Supply Chain Performance of Supermarkets in Nairobi, Kenya. University of Nairobi, Nairobi.

[9] Pasiopoulos, A., Siskou, O., Galanis, P., Prezerakos, P., Moisoglou, I., Theodorou, M. and Kaitelidou, D. (2013) The Implementation of e-Procurement System in Health Sector in Greece: Attitudes of Potential Users and Implications for Hospital Management. International Journal of Health Research and Innovation, 1, 15-23.

[10] Davis, F.D. (1986) A Technology Acceptance Model for Empirically Testing New End-User Information Systems: Theory and Results. Ph.D. Dissertation, MIT Sloan 
School of Management, Cambridge, MA.

[11] Sakala, L. and Phiri, J. (2019) Factors Affecting Adoption and Use of Mobile Banking Services in Zambia Based on TAM Model. Open Journal of Business and Management, 7, 1380-1394. https://doi.org/10.4236/ojbm.2019.73095

[12] Soneka, P.N. and Phiri, J. (2019) A Model for Improving E-Tax Systems Adoption in Rural Zambia Based on the Tax Model. Open Journal of Business and Management, 7, 908-918. https://doi.org/10.4236/ojbm.2019.72062

[13] Daka, C.G. and Phiri, J. (2019) Factors Driving the Adoption of E-banking Services Based on the UTAUT Model. International Journal of Business and Management, 14, pp. https://doi.org/10.5539/ijbm.v14n6p43

[14] World Bank (2017) Improving Public Sector Performance through Innovation and Inter-Agency Coordination. Pioneering E-Procurement in Africa, Rwanda. http://documents.worldbank.org/curated/en/833041539871513644/122290272_2018 11348025153/additional/131020-WP-P163620-WorldBankGlobalReport-PUBLIC.p df

[15] Creswell, J.W. (2013) Research Design: Qualitative, Quantitative, and Mixed Methods Approaches. 4th Edition, SAGE Publications, Thousand Oaks, CA.

[16] Polit, D.F. and Hungler, P.B. (1999) Nursing Research: Principles and Methods. 6th Edition, Lippincott Williams \& Wilkins, Philadelphia, PA.

[17] IBM Corp (2015) IBM SPSS Statistics for Windows, Version 23.0. IBM Corp, Armonk, NY. 